\title{
The Development Of Teaching Video Media Based On Tri Kaya Parisudha In Educational Psychology Courses
}

\author{
Dewa Ayu Made Manu Okta Priantini \\ Program Studi Pendidikan Guru Sekolah Dasar, Universitas Dwijendra Denpasar. \\ Email:dewaayumanu56@gmail.com
}

\section{A R T I C L E I N F O \\ Article history: \\ 1 Agustus 2020 Received in revised form \\ 20 September 2020 \\ Accepted 10 November 2020 \\ Available online 20 \\ November 2020 \\ Kata Kunci: \\ Pengembangan, Video \\ Pembelajaran, Tri Kaya \\ Parisudha \\ Keywords: \\ Development, Learning \\ Video, Tri Kaya Parisudha.}

\begin{abstract}
A B S T R A K
Permasalahan yang melatar belakangi penelitian ini adalah pelaksanaan pembelajaran pada mata kuliah psikologi pendidikan yang cenderung membosankan dan hasil belajar yang rendah. Penelitian ini merupakan penelitian pengembangan (research and devlopment). Subyek uji coba penelitian merupakan mahasiswa dari Prodi PGSD. Data yang dikumpulkan dalam penelitian ini adalah data dari uji ahli isi mata pelajaran, uji ahli desain, uji ahli media pembelajaran, dan dari uji coba mahasiswa. Instrumen pengumpulan data yang digunakan berupa lembar evaluasi (angket). Analisis data menggunakan analisis deskriptif kualitatif dan deskriptif kuantitatif. Hasil penilaian terhadap produk media dilaksanakan berdasarkan enam aspek, yaitu: aspek isi bidang studi dengan persentase tingkat pencapaian $88.05 \%$ dengan predikat layak; ditinjau dari aspek desain pembelajaran dengan persentase tingkat pencapaian $84.65 \%$ predikat layak; ditinjau dari aspek media pembelajarandengan persentase tingkat pencapaian $87.00 \%$ predikat layak; ditinjau dari aspek uji coba perorangan,dengan persentase tingkat pencapaian $91.55 \%$ pedikat sangat layak; uji coba kelompok kecil, dengan persentase tingkat pencapaian $93.40 \%$ predikat sangat layak; dan ditinjau dari aspek uji coba lapangan dengan persentase tingkat pencapaian $92.46 \%$ predikat sangat layak.
\end{abstract} Dengan demikian produk media video pembelajaran ini memiliki tingkat validitas yang baik dan layak untuk digunakan dalam proses pembelajaran pada mata kuliah Psikologi Pendidikan.

\begin{abstract}
A B S T R A C T
This research aimed to implement learning in educational psychology courses that tend to be boring and have low learning outcomes. This research was a research and development (research and development). The research trial subjects were students from the PGSD Study Program. The data collected in this study were data from subject content expert tests, design expert tests, instructional media expert tests, and student trials. The data collection instrument was an evaluation sheet (questionnaire) for both expert testing and student testing. Data analysis used qualitative descriptive analysis and quantitative descriptive analysis. The results of the assessment of media products were carried out based on six aspects, namely: content aspects of the field of study / with the percentage of the achievement level of $88.05 \%$ with the title feasible; In terms of the learning design aspect, the percentage of achievement level was $84.65 \%$, the predicate was feasible; in terms of the learning media aspect with the achievement level percentage of $87.00 \%$, the predicate was feasible; In terms of the individual trial aspect, the percentage level of achievement of $91.55 \%$ predicates was very feasible; small group trial, with the percentage level of achievement of $93.40 \%$ predicate very feasible; and viewed from the aspect of field trials with the percentage level of achievement of $92.46 \%$ predicate very feasible. Thus, this instructional video media product had a good validity level and was suitable for the Educational Psychology course's learning process.
\end{abstract}

\section{Introduction}

The world today, including Indonesia, has been troubled by the Covid-19 virus pandemic. This Corona virus's characteristic is its very high spread (Fitriyani et al., 2020; Kurniati et al., 2020; Pratama et al., 2020). Various policies have been implemented. These policies have led to the implementation of learning to be implemented by distance learning. The distance learning system requires educators to be able to make the best use of technological media. Following the era of the industrial revolution 4.0 implemented by Indonesia today, science and technology are developing rapidly. Technology has become an inseparable part of all aspects of human life, one of which is education.

Education is always required to adjust technological developments to improve the quality of education, especially adjusting its use for the world of education, especially in the learning process. Learning that used information technology can make it easy for students to obtain information and learning resources by making educators as facilitators. The development of technology that is well used in the world of education certainly positively influences learning implementation. Because of technology, learning implementation can be done 
anywhere without being in the room or can be done without meeting face-to-face. (Firdaus \& Suprapto, 2018; Najwa \& Susanto, 2018; Tantu \& Christi, 2020).

Along with the times and the current pandemic, educators must continue to carry out effective and efficient learning activities by designing their learning and taking advantage of information technology-based learning media. Effective learning includes two main things, namely active learning time and learning quality. Active learning time is related to the amount of time students use during learning and how students are involved in achieving predetermined learning objectives, then related to the quality of learning, namely the interaction between educators and students during learning implementation. Dale explained that students would experience firsthand the learning learned in the cone of experience by utilizing learning media as a tool so that the material obtained can be easily understood and stored in long-term memory. (Maufur \& Lisnawati, 2017; Pranowo \& Prihastanti, 2020; Pujianingtias et al., 2019).

Learning media is important in the learning process because learning media is a tool or channel for messages that can represent the teacher in conveying information in a more thorough, clear, and interesting way and makes it easier for students to understand the learning material presented. Learning media can be interpreted as something that can convey or channel messages from a source in a planned manner, resulting in a conducive learning environment where the recipient can efficiently and effectively carry out the learning process and stimulate students' willingness to learn. (Bahtiar, 2019; Purbarani et al., 2018; Ulya \& Rofian, 2019).

Learning media are generally used to make the learning process more effective and efficient, following the desired learning objectives. For the learning media to be more attractive, supporting applications must be added so that the learning process becomes more interesting, innovative, and interactive. Learning media is important because learning media will arouse student interest and motivation, reduce verbalism as a channel of information, encourage students, and increase knowledge retention in learning. The use of selected learning media can influence the success of learning. In general, learning media benefits facilitate interaction between teachers and students so that learning activities are more effective and efficient (Herliana \& Anugraheni, 2020; Sari \& Suswanto, 2017; Widiana et al., 2019). The use of instructional media needs to be used in all subjects, the Educational Psychology subject.

However, based on the results of interviews with several Elementary School Teacher Education study program students and through observation, it was found that the average score in the Educational Psychology subject for second-semester students was still not satisfactory 60.75 (in the second semester of the 2019/2021 academic year. This score tends to be low. This problem occurs because learning tends to be boring so that students are less motivated to learn. It also occurs because educators tend to explain with the lecture method without using interesting media. The lecture method is considered less attractive because the learning that takes place is only centred on educators and students only as listeners (Maufur \& Lisnawati, 2017; Sundari, 2019; Ulfah \& Soenarto, 2017).

Educational psychology itself is a branch of psychology which is a science that talks about human behavior in the learning process (Azwar, 2016; Febrayosi, 2019; Septiani \& Nasution, 2018). In the teaching process, educators must master the material to be explained and master various methods of delivering material and use interesting learning media to be interested in learning and have high motivation. In this period of distance learning, learning media suitable for use in audio-visual media. In this study, one of the solutions that can be used is the development of instructional videos.

Video is a learning media classified as an audio-visual type. This media has an object moving together with natural sounds or appropriate sounds. Media with this type of video tends to make students easily remember and understand lessons because it does not use one type of sense but two senses at once, namely the eyes and ears. The advantages of instructional video media are that they can provide messages that can be accepted more evenly by students, effective in explaining a process, overcoming space and time limitations, more realistic, can be repeated and stopped as needed, provide a deep impression that can affect student attitudes (Muliani \& Wibawa, 2019; Rante et al., 2013; Yuniarni et al., 2020).

Learning media will give a more attractive impression when combined with the local wisdom of each region. Bali is famous for a lot of local wisdom, one of which is Tri Kaya Parisudha. Tri Kaya Parisudha is three types of actions that form the basis of the ethical teachings of Hinduism in living life, which consist of: (1) Kayika parisudha is a good deed which is the practice of good thoughts and words; (2) Wacika is a good word, heard by everyone; (3) Manacika parisudha is good thinking (Dewi et al., 2014; Suanthara, 2018; Widyanto, 2020). Tri Kaya Parisudha must be carried out anytime, anywhere, and with anyone. Tri Kaya Parisudha can be carried out through a learning process. Tri Kaya Parisudha is integrated with a learning video. The resulting video will stimulate students to think, then argue using good and correct words and behave well so that learning will be more meaningful.

There have been many studies that have been carried out related to this media. Supporting research is carried out by (Kurniawan et al., 2018), which states that the media developed is in the effective category. The instructional video media that has been developed are categorized as valid and effective in learning activities. 
The second research was conducted by (Riyanto et al., 2019), which shows that the students managed to score above the KKM. Thus, the development of instructional video media is effective for use in the learning process. Further research related to Tri Kaya Parisudha was carried out by (Dewi et al., 2014), which shows the results that $\mathrm{t}$ hitung $>\mathrm{t}$ table, $\mathrm{t}$ hitung $=6.602$, and $\mathrm{t}$ table $=1.671$ and is supported by the difference in the average score obtained by students who are taught using the VCT model based on the Tri Kaya Parisudha concept, namely 121 who are in the high category and direct instruction model, 109,12 which are in the medium category. Thus it can be concluded that the integration of Tri Kaya Parisudha in learning gives positive results. Based on some of the previous research results, the update of this research is the development of instructional video media integrated with Tri Kaya Parisudha's local wisdom, which is expected to impact the implementation of learning positively.

The purpose and focus of this research is to develop learning media for learning videos based on Tri Kaya Parisudha in Educational Psychology Subject for Students at Prodi Pendidikan Guru Sekolah Dasar, Fakultas Keguruan dan Ilmu Pendidikan, Universitas Dwi Jendra 2019/2020.

\section{Method}

This research is development research. This research method is used to produce certain products and test the effectiveness of these products. The research carried out took the target at the college level. The research subjects were students of the Dwi Jendra University Primary School Teacher Education study program for the 2019/2020 academic year in the even semester. The development model used is the ADDIE model, consisting of analysis, design, development, implementation, and evaluation stages (Ario \& Asra, 2019; Wati, 2013; Yuniarni et al., 2020). The ADDIE model design can be seen in Figure 1.

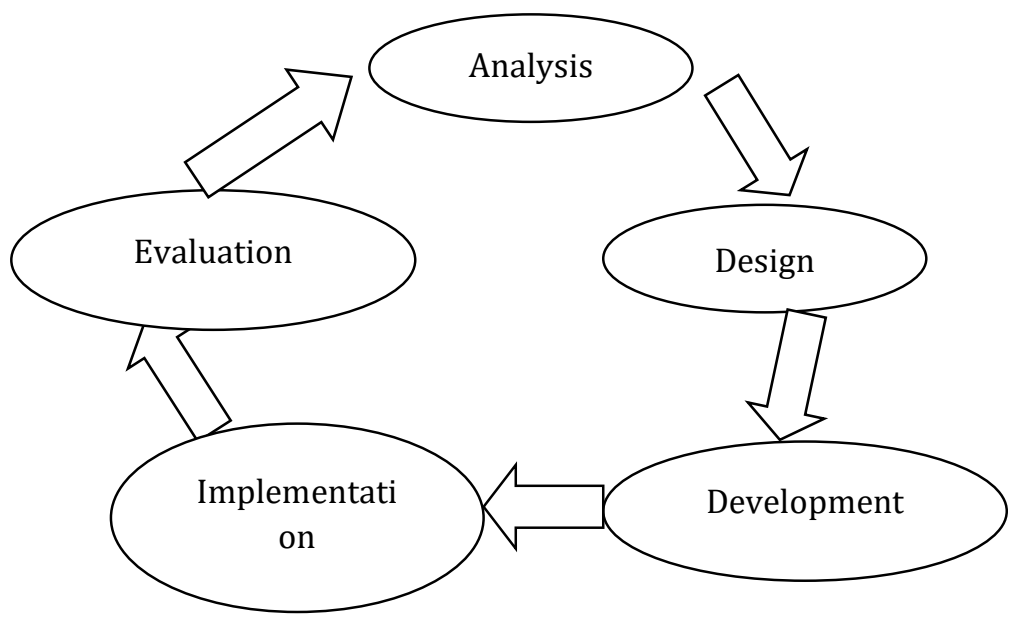

Gambar 1. Desain Model ADDIE

The data collection technique used in developing instruments, including observation for development purposes from the early stages of identifying problems to the testing stage. The interview guide instrument is used to collect various information related to the video's content to be developed, deepen the product study during the trial (completing the things that need further explanation from the questionnaire). Furthermore, developing a questionnaire is used to determine the percentage of product eligibility in expert trial and audience trials (students). In the product validity test, the development of instructional videos is validated through expert reviews, namely: (a) subject content experts, (b) instructional media experts (c) instructional design experts. Also, validation also through product testing includes: (a) individual trials, (b) small group trials, (c) field trials. In the product effectiveness test stage, effectiveness is carried out by collecting data on student learning outcomes using pre-test and post-test on the material to be tested. The pre-test tests students' initial abilities before using interactive learning media.

On the other hand, the post-test is the final activity to test the students' ability to the material that has been given using instructional videos. In this development research, the effectiveness test uses descriptive qualitative techniques and inferential statistics. There are two types of data generated, namely qualitative data and quantitative data.

The data analysis technique used is descriptive qualitative analysis techniques and quantitative descriptive data analysis. The qualitative descriptive analysis technique is used to process data from the review of content experts in the field of study or subject, learning product design experts, instructional media experts, 
and student trial results. The results of this analysis are then used to revise the product being developed. Meanwhile, quantitative descriptive analysis is used to process the data obtained through a questionnaire in the form of scores. The data analysis results are seen from the percentage of high and low needs desired by the subjects who target this study.

\section{Result and Discussion}

The results of the development research made are presented in three main topics, namely data presentation and data analysis, revision of learning media products, and discussion of products that have been made. Presentation and data analysis are further described in four sub-discussed. The four sub-subjects include the subject content expert test, the learning design expert test, the learning media expert test, and the field trial. According to experts, the validity of learning video development can be seen in Table 1.

Table 1. Results of the Validity of Learning Video Development according to Experts

\begin{tabular}{|c|c|c|}
\hline Trial Subject & Validity result (\%) & Information \\
\hline \multicolumn{3}{|l|}{ Course content expert } \\
\hline \multicolumn{3}{|c|}{ Test of instructional designexperts } \\
\hline \multicolumn{3}{|c|}{ Test of instructional media experts } \\
\hline \multicolumn{3}{|c|}{ individual trials } \\
\hline \multicolumn{3}{|l|}{ Small Group Trial } \\
\hline Field Trial & & \\
\hline
\end{tabular}

This product has been tested and assessed by a course content expert in the Course Content Expert Test stage. During the trial, the special expert for this course used a questionnaire instrument. After being converted to the PAP conversion table for the achievement level scale of 5, the achievement level percentage is $88.05 \%$ with good / proper qualifications, so there is no need for revision. The presentation of material on the media follows the demands of achieving predetermined competency standards and basic competencies. This media is also supported by the suitability of animation, images, text, sound in the video to understand the material easily, and learning becomes more interesting.

Learning Design Expert Test is carried out in the second stage after getting an assessment from the course content expert test. After getting an assessment from subject content experts, the media developed was tested on learning design experts to get assessments, comments, and suggestions for products in terms of learning design. Learning media were tested on a learning design expert. After being converted to the Pap conversion table for the achievement level scale of 5, the achievement level percentage is $84.65 \%$ with good / proper qualifications and does not need to be revised. This media follows the predetermined indicators. The presentation of the material presented in the form of images, animation, text, and sound that is easy to understand and interesting to learn.

The learning media expert test is carried out in the third stage after the subject content expert's trial and the media learning design expert. The instructional video media product was tested on a learning media expert. After being converted to the PAP conversion table, the achievement level of a scale of 5, the percentage of the achievement level is $87.00 \%$ with the good result due to the quality of the animation display, the aesthetic score of the animation presentation, the overall ease of operation on the learning video so that according to the media expert test, the media it doesn't need to be revised.

The fourth stage is testing the instructional media for individuals. The subjects used as the subject of this study were students of the Elementary School Teacher Education study program, amounting to 3 students. After being converted to the PAP conversion table for the achievement level scale of 5, the achievement level percentage is $91.55 \%$, with good qualification. The elements that support learning video media are suitable: the suitability of the image layout with text, the quality of the sound effect/fx, the level of ease of use of the media, the clarity of the instructions for using the media. The material can be conveyed properly, not boring. It can motivate students in learning, and the media no longer need to be revised.

The fifth stage is the Small Group Trial. This trial was carried out after going through the individual trial stage, involving 15 respondents or students. The assessment, which 15 students carried out, was still focused on the material and media aspects, both physical and non-physical, including the operation's technical point of view. After being converted to the Pap conversion table, the level of achievement on a scale of 5, the percentage level of achievement is $93.40 \%$ with good result of conformity to the layout of the image with text, quality of sound effect/fx, level of ease of use of media, clarity of instructions for media use on instructional video media 
to make the material presented more interesting, fun and motivate students in learning. This media does not need to be revised.

The last stage that was carried out was the Field Trials. After going through the individual trial stage and small group trial involving twenty students as respondents, this field trial was carried out. The assessments carried out are still focused on the material and media aspects as a whole, both physical and non-physical, including the technical point of view of operations. After being converted to the PAP conversion table, the achievement level of a scale of 5, the percentage level of achievement is $92.46 \%$ with very good qualifications in the suitability of image layout with text, quality of sound effect/fx, level of ease of use of media, clarity of instructions for using media on instructional video media to make the material presented is more interesting, fun and motivates students in learning. This media does not need to be revised.

Based on the stages passed previously, product development revision is carried out to produce better and better quality products. At this stage, the revision of instructional video media products is explained based on comments and suggestions from experts and students who are used as respondents. From the trial stages carried out, product revisions are presented sequentially, starting from subject content experts, learning design experts, instructional media experts, individual trials, small group trials, to field trials. Based on the subject content experts' assessment, the instructional video media reached a very good level of achievement, so it did not need to be revised. Based on the learning design experts' assessment during the learning design experts' trial stage, the resulting product has reached a good achievement level, so it does not need to be revised. However, based on the respondents' suggestions, this media is deemed necessary to improve the developed products. The assessment results on individual trials, small group trials, and field trials showed no suggestions for revising the instructional video media products. Three students appointed as respondents did not give comments, so this product was no longer revised.

This development research produces a product in the form of instructional video media. The learning media produced are first assessed by several experts, such as content experts, learning design experts, and instructional media experts. After getting reviews/assessments from experts, the learning media was revised according to the input provided. This media was tested at Dwi Jendra University, especially in the Elementary School Teacher Education study program. Based on the results of validation by experts and field trials, it can be seen that the quality of the learning video media developed is good. From these aspects, it can be concluded that the learning video media developed are included in the good criteria and suitable for learning. Media that are at a good achievement level need not be revised. However, based on experts' and students' responses during product trials, it is necessary to improve the media components according to the input given for the media's perfection.

The use of appropriate learning media can be used to implement the learning process to become an intermediary for students to understand the material and improve learning quality. Some of the benefits of using learning media are clarifying the meaning of material and verbalizing. Learning becomes more varied, active, interesting, and overcomes space limitations (Bahtiar, 2019; Kurniawan et al. Learning media in the form of instructional videos. By utilizing instructional video, media can improve student learning outcomes because video media can attract interest in learning because it contains images and sounds that can make students want to ask questions and increase knowledge to impact learning outcomes.

Audio-visual learning media (video) is an intermediary medium whose absorption is through sight and hearing to build conditions that enable students to acquire knowledge, skills, or attitudes used to help achieve learning goals (Febryanto, 2015; Louk \& Sukoco, 2016; Suria Oktaviani et al., 2019). Video can produce moving shows as well as produce sound. In addition, video shows can display an image enlargement format, control viewing such as speeding up, slowing down, or repeating what is deemed necessary so that the implementation of learning can be controlled directly by the educator according to the needs learning objectives to be achieved.

In this study, instructional video media is integrated with local wisdom, namely Tri Kaya Parisudha. Tri Kaya Parisudha is three kinds of actions that must be purified. Manacika behavior is based on good, holy, and right thoughts. Manacika behavior based on good thoughts, and right. And Kayika is behavior based on good thoughts, and right (Dewi et al., 2014; Lestari, 2018; Suanthara, 2018). With the application of Tri Kaya Parisudha in learning, students will get used to thinking well, saying good things, and behaving well. It becomes support during learning and is more shown when students respond to or pay attention to the instructional video. This integration then has a positive impact and renewal in research, which can later be applied during educational psychology courses or other subjects.

Supporting relevant research is research conducted by (Wati, 2013) which shows the results that the use of instructional videos in the teaching and learning process plays an important role in improving student cognitive learning outcomes, this is because the media is a tool or an intermediary for teachers to deliver learning material, especially in social studies subjects for grade IV SDN Babatan 1/456. Further research was carried out by (Ario \& Asra, 2019), which shows that video validity is in the very good category. The practicality of the video is in a good category. The video's effectiveness is in a good category so that the learning video has a 
positive impact. Furthermore, research related to Tri Kaya Parisudha was carried out by (Suanthara, 2018) which shows the results that there is an effect of Tri Kaya Parisudha's learning on learning achievement in the Fifth Semester Student MPP course at STKIP Agama Hindu Singaraja. From several research results related to video lessons and Tri Kaya Parisudha, it can be concluded that the integration of learning videos with Tri Kaya Parisudha has a positive impact and effectively used to improve learning outcomes in educational psychology courses.

\section{Conclusion}

This development research produces a product in the form of instructional video media. Based on the results of validation by experts and field trials, it can be seen that the quality of the learning video media developed is good/feasible. From these aspects, it can be concluded that the instructional video media developed are included in good criteria. Thus, this instructional video media product has a good validity level and is suitable for the Educational Psychology course's learning process.

\section{References}

Ario, M., \& Asra, A. (2019). Pengembangan Video Pembelajaran Materi Integral Pada Pembelajaran Flipped Classroom. Aksioma: Jurnal Program Studi Pendidikan Matematika, 8(1). https://doi.org/http://dx.doi.org/10.24127/ajpm.v8i1.1709

Azwar, S. (2016). Efek Seleksi Aitem Berdasar Daya Diskriminasi Terhadap Reliabilitas Skor Tes. Buletin Psikologi, 17(1). https://doi.org/https://doi.org/10.22146/bpsi.11479

Bahtiar, R. S. (2019). Efektivitas Penggunaan Media Papan Waktu Pada Pembelajaran Penghitungan Waktu Bagi Siswa Kelas Iii Sekolah Dasar. Jurnal Bidang Pendidikan Dasar, 3(1), 14-23. https://doi.org/10.21067/jbpd.v3i1.2857

Dewi, A. A. I. R. M., Murda, I. N., \& Tegeh, I. M. (2014). Pengaruh Model VCT Berlandaskan Konsep Tri Kaya Parisudha Terhadap Hasil Belajar Ranah Afektif Siswa Kelas V Di SD Gugus III Kecamatan Seririt Kabupaten Buleleng Tahun Pelajaran 2013/2014. Mimbar PGSD Undiksha, 2(1). https://doi.org/http://dx.doi.org/10.23887/jjpgsd.v2i1.2430

Febrayosi, P. (2019). Estimasi True Score pada Second Order Unidimensional Data: Sebuah Studi Simulasi Monte Carlo Tentang Dampak Panjang Tes, Tingkat Kesukaran dan Daya Pembeda Item. Jurnal Pengukuran Psikologi Dan Pendidikan Indonesia, https://doi.org/https://doi.org/10.15408/jp3i.v1i4.10726

Febryanto, F. N. (2015). Pembelajaran Lay Up Shoot Menggunakan Media Audio Visual Basic Lay Up Shoot Untuk Meningkatkan Hasil Belajar Lay Up Shoot Pada Siswa Kelas Viiia Smp Kanisius Pati Tahun 2013/2014. E-Jurnal Physical Education, Sport, Health and Recreation, 4(1), 1509-1521. https://doi.org/10.15294/active.v4i1.4548

Firdaus, N. Z., \& Suprapto. (2018). Evaluasi Manajemen Risiko Teknologi Informasi Menggunakan COBIT 5 IT Risk (Studi Kasus : PT . Petrokimia Gresik). Jurnal Pengembangan Teknologi Informasi Dan Ilmu Komputer, 2(1), 91-100. https://doi.org/10.21460/jutei.2018.12.53

Fitriyani, Y., Fauzi, I., \& Sari, M. Z. (2020). Motivasi Belajar Mahasiswa Pada Pembelajaran Daring Selama Pandemik Covid-19. Jurnal Kependidikan: Jurnal Hasil Penelitian Dan Kajian Kepustakaan Di Bidang Pendidikan, Pengajaran Dan Pembelajaran, 6(2), 165-175. https://doi.org/10.23917/ppd.v7i1.10973

Herliana, S., \& Anugraheni, I. (2020). Pengembangan Media Pembelajaran Kereta Membaca Berbasis Kontekstual Learning Siswa Sekolah Dasar. Jurnal Basicedu, 4(2), 314-326. https://doi.org/10.31004/basicedu.v4i2.346

Kurniati, E., Nur Alfaeni, D. K., \& Andriani, F. (2020). Analisis Peran Orang Tua dalam Mendampingi Anak di Masa Pandemi Covid-19. Jurnal Obsesi: Jurnal Pendidikan Anak Usia Dini, 5(1), 241. https://doi.org/https://doi.org/10.31004/obsesi.v5i1.541

Kurniawan, D. C., Kuswandi, D., \& Husna, A. (2018). Pengembangan Media Video Pembelajaran Pada Mata Pelajaran IPA Tentang Sifat Dan Perubahan Wujud Benda Kelas IV SDN Merjosari 5 Malang. Jinotep: Jurnal Inovasi Dan Teknologi Pembelajaran, $4(2)$. https://doi.org/http://dx.doi.org/10.17977/um031v4i22018p119 
Lestari, I. (2018). Penerapan Metode Pembelajaran Diskusi Dan Resitasi Dalam Meningkatkan Hasil Belajar Pendidikan Agama Hindu Siswa Kelas IV SD Negeri 2 Tumbu Karangasem. Jurnal Penjaminan Mutu, 4. http://ejournal.ihdn.ac.id/index.php/JPM/article/view/398

Louk, M. J. H., \& Sukoco, P. (2016). Pengembangan Media Audio Visual Dalam Pembelajaran Keterampilan Motorik Kasar Pada Anak Tunagrahita Ringan. Jurnal Keolahragaan, 4(1), 24-33. https://doi.org/10.21831/jk.v4i1.8132

Maufur, S., \& Lisnawati, S. (2017). Pengaruh Penggunaan Media Gambar Berseri Terhadap Keterampilan Berbicara Bahasa Indonesia Siswa Kelas III MI Al-Washliyah Perbutulan Kabupaten Cirebon. Al Ibtida: Jurnal Pendidikan Guru MI, 4(2), 189. https://doi.org/10.24235/al.ibtida.snj.v4i2.1888

Muliani, N. K. D., \& Wibawa, I. M. C. (2019). Pengaruh Model Pembelajaran Inkuiri Terbimbing Berbantuan Video Terhadap Hasil Belajar IPA. Jurnal Ilmiah Sekolah Dasar, 3(1), 107-114. https://doi.org/http://dx.doi.org/10.23887/jisd.v3i1.17664

Najwa, N. F., \& Susanto, T. D. (2018). Kajian dan Peluang Penelitian Tata Kelola Teknologi Informasi: Ulasan Literatur. Jurnal Teknologi Informasi Dan Ilmu Komputer, 5(5), 517. https://doi.org/10.25126/jtiik.201855827

Pranowo, T. A., \& Prihastanti, A. (2020). Pengaruh Bimbingan Kelompok Melalui Media Audio Visual Terhadap Motivasi Belajar Siswa. Indonesian Journal of Learning Education and Counseling, 2(2), 217-223. https://doi.org/10.31960/ijolec.v2i2.338

Pratama, L. D., Lestari, W., \& Astutik, I. (2020). Efektifitas Penggunaan Media Edutainment Di Tengah Pandemi Covid-19. AKSIOMA: Jurnal Program Studi Pendidikan Matematika, 9(2), 413-423. https://doi.org/10.24127/ajpm.v9i2.2783

Pujianingtias, E. N., Saputra, H. J., \& Muhajir. (2019). Pengembangan Media Majamat pada Materi Pecahan Pada Mata Pelajaran Matematika. Jurnal Penelitian Dan Pengembangan Pendidikan, 3(3), 257-263. https://doi.org/http://dx.doi.org/10.23887/jppp.v3i3.19261

Purbarani, D. A., Dantes, N., \& Adnyana, P. B. (2018). Pengaruh Problem Based Learning Berbantuan Media Audio Visual Terhadap Kemampuan Berpikir Kritis Dan Hasil Belajar Ipa Di Sekolah Dasar. Pendasi: Jurnal Pendidikan Dasar Indonesia, 2(1), 24-34. https://doi.org/10.23887/jpdi.v2i1.2689

Rante, P., Sudarto, \& Ihsan, N. (2013). Pengembangan multimedia pembelajaran fisika berbasis audio-video eksperimen listrik dinamis di smp. Jurnal Pendidikan IPA Indonesia, 2(2), 203-208. https://doi.org/10.15294/jpii.v2i2.2724

Riyanto, M., Jamaluddin, U., \& Pamungkas, A. S. (2019). Pengembangan Video Pembelajaran Berbasis Aplikasi Video Scribe Pada Mata Pelajaran IPS di Sekolah Dasar. Madrasah: Jurnal Pendidikan Dan Pembelajaran Dasar, 11(2). https://doi.org/https://doi.org/10.18860/madrasah.v11i2.6419

Sari, H. V., \& Suswanto, H. (2017). Pengembangan Media Pembelajaran Berbasis WEB Untuk Mengukur Hasil Belajar Siswa Pada Mata Pelajaran Komputer Jaringan Dasar Program Keahlian Teknik Komputer Dan Jaringan. Jurnal Pendidikan: Teori, Penelitian, Dan Pengembangan, 2(7), 1008-1016. https://doi.org/https://doi.org/10.17977/jptpp.v2i7.9734

Septiani, D., \& Nasution, I. N. (2018). Peran Keterlibatan Ayah dalam Pengasuhan Bagi Perkembangan Kecerdasan Moral Anak. Jurnal Psikologi, 13(2), 120. https://doi.org/10.24014/jp.v13i2.4045

Suanthara, I. N. D. E. (2018). Pengaruh Model Pembelajaran Tri Kaya Parisudha Terhadap Prestasi Belajar Mahasiswa Semester V Prodi Pendidikan Agama Hindu STKIP Agama Hindu Singaraja Tahun Akademik 2016/2017. Pasupati: Journal of Hindu Studies \& Ducation, 5(2). https://doi.org/http://dx.doi.org/10.37428/pspt.v5i2.31

Sundari, N. (2019). Penggunaan Media Gambar dalam Meningkatkan Keaktifan Siswa dalam Pembelajaran Pengetahuan Sosial di Sekolah Dasar. Journal of Chemical Information and Modeling, 53(9), 16891699. https://doi.org/10.1017/CBO9781107415324.004

Suria Oktaviani, M. D., Suwatra, I. W., \& Murda, N. (2019). Pengaruh Model Pembelajaran Snowball Throwing Berbantuan Media Audiovisual terhadap Hasil Belajar Bahasa Indonesia. Jurnal Ilmiah Sekolah Dasar, 3(1), 89. https://doi.org/10.23887/jisd.v3i1.17662

Tantu, Y. R. P., \& Christi, L. Y. (2020). Analisis Pelaksanaan Microteaching Mahasiswa PGSD Pada Mata 
Kuliah PSAP Sains Dan Teknologi. Jurnal Basicedu, 3(2), 707-715. https://doi.org/https://doi.org/10.31004/basicedu.v4i3.424

Ulfah, D. M., \& Soenarto, S. (2017). Pengaruh penggunaan media video dan gambar terhadap keterampilan menulis kelas V. Jurnal Prima Edukasia, 5(1), 22-34. https://doi.org/10.21831/jpe.v5i1.7693

Ulya, H., \& Rofian, R. (2019). Pengembangan Media Story Telling Berbasis Montase Sederhana Sebagai Suplemen Bahan Ajar Tema Peduli Terhadap Makhluk Hidup Kelas IV Sekolah Dasar. Jurnal Pendidikan Dasar Nusantara, 5(1), 140-149. https://doi.org/10.29407/jpdn.v4i2.12166

Utami, Y. S. (2020). Penggunaan Media Gambar Untuk Meningkatkan Hasil Belajar Siswa Dalam Pembelajaran IPA. Jurnal Pendidikan Dan Konseling (JPDK), 1(2), 122-127.

Wati, L. A. (2013). Pemanfaatan Media Video Pembelajaran Untuk Meningkatkan Hasil Belajar IPS Pada Siswa Kelas IV SDN Babatan I/456 Surabaya. Jurnal Penelitian Pendidikan Guru Sekolah Dasar, 1(1). https://jurnalmahasiswa.unesa.ac.id/index.php/jurnal-penelitian-pgsd/article/view/792

Widiana, I. W., Rendra, N. T., \& Wulantari, N. W. (2019). Media Pembelajaran Puzzle Untuk Meningkatkan Hasil Belajar Siswa Kelas IV Pada Kompetensi Pengetahuan IPA. Indonesian Journal Of Educational Research and Review, 2(3), 354-362. https://doi.org/http://dx.doi.org/10.23887/ijerr.v2i3.22563

Widyanto, I. P. (2020). Peningkatan Mutu Pendidikan Hindu Melalui Pengelolaan Pembelajaran. Jurnal Penjaminan Mutu, 6(1), 48-59. https://doi.org/http://dx.doi.org/10.25078/jpm.v6i1.1151

Yuniarni, D., Sari, R. P., \& Atiq, A. (2020). Pengembangan Multimedia Interaktif Video Senam Animasi Berbasis Budaya Khas Kalimantan Barat. Jurnal Obsesi : Jurnal Pendidikan Anak Usia Dini, 4(1), 290. https://doi.org/10.31004/obsesi.v4i1.331 